\title{
ANALISIS PELAKSANAAN PROGRAM POS PEMBINAAN TERPADU PENYAKIT TIDAK MENULAR DI WILAYAH KERJA PUSKESMAS CIBUNGBULANG TAHUN 2019-2020
}

\author{
Silviatu Sa'adah' ${ }^{1}$, Siti Khodijah Parinduri' ${ }^{2}$, Eny Dwimawati ${ }^{3}$ \\ ${ }^{1}$ Konsentrasi Manajemen Pelayanan Kesehatan Program (MPK), Program Studi Kesehatan Masyarakat Fakultas \\ Ilmu Kesehatan Universitas Ibn Khaldun Bogor. Email : silviatusaadah@gmail.com \\ 2,3Program Studi Kesehatan Masyarakat Fakultas Ilmu Kesehatan Universitas Ibn Khaldun Bogor. ${ }^{3}$ Program Studi \\ Kesehatan Masyarakat Fakultas Ilmu Kesehatan Universitas Ibn Khaldun Bogor
}

\begin{abstract}
Abstrak
Penyakit tidak menular (PTM), juga dikenal sebagai penyakit kronis, tidak ditularkan dari orang ke orang, mereka memiliki durasi yang panjang dan pada umumnya berkembang secara lambat. Puskesmas Cibungbulang adalah salah satu puskesmas di Kabupaten Bogor yang mengadakan program pos pembinaan terpadu penyakit tidak menular PTM. Penelitian ini bertujuan untuk mengetahui bagaimana pelaksanaan program Posbindu PTM di Puskesmas Cibungbulang Kabupaten Bogor Tahun 2019-2020. Jenis penelitian ini adalah penelitian kualitatif yang bersifat deskriptif. Teknik yang digunakan dalam pengambilan sampel adalah purposive sampling. Informan pada penelitian ini adalah kepala puskesmas, pelaksana program, penanggung jawab program, kader posbindu dan peserta posbindu PTM. Instrumen yang digunakan adalah wawancara mendalam, observasi dan telaah dokumen. Hasil penelitian menunjukan bahwa sumber daya manusia sudah mencukupi, pembiayaan dari dana bantuan operassional kesehatan, anggaran pendapatan dan belanja daerah, anggaran dana desa, yayasan baitul mal dan dana sehat dari peserta, puskesmas sudah mempunyai standar operasional prosedur, sarana dan prasarana masih belum bisa mencangkup keseluruhan kegiatan posbindu PTM terutama alat-alat kesehatannya, kader sudah dilatih tetapi hanya perwakilan, alur pelayanan sudah menggunakan sistem 5 meja walaupun ada 2 posbindu yang pertama tahap yang tidak berurutan dan yang kedua terkadang tahap tersebut berjalan dan tidak, proses rujukan hanya di berikan surat rujukan untuk peserta datang ke puskesmas langsung, pencatatan dan pelaporan hasil kegiatan posbindu PTM berbentuk buku kohort. Bentuk monitoring pihak puskesmas seperti dalam lokakarya mini, lokakarya bulanan, pengawasan Dinas Kesehatan yaitu hanya dengan melihat laporan setiap bulannya. Kesimpulan penelitian ini adalah program posbindu di Puskesmas Cibungbulang Kabupaten Bogor belum dilaksanakan secara optimal. Perlu memberikan pelatihan, meningkatkan peran serta masyarakat agar cakupannya tercapai dan melengkapi sarana prasarana.
\end{abstract}

Kata Kunci : Analisis, Pelaksanaan, Posbindu PTM

\section{PENDAHULUAN}

Kesehatan merupakan hak asasi manusia yang harus dilindungi dan diperhatikan oleh pemerintah. Kesehatan juga merupakan salah satu indikator penting dalam menentukan kesejahteraan suatu bangsa di samping ekonomi dan sosial. Hal ini ditegaskan dalam UndangUndang Dasar (UUD) tahun 1945 pasal 28 H ayat 1, yang menyatakan bahwa setiap orang 
berhak memperoleh pelayanan kesehatan. Selain itu Undang-undang (UU) Nomor 36 tahun 2009 tentang kesehatan juga menjelaskan dengan tegas hak dan kewajiban pemerintah maupun masyarakat yang berkenaan dengan pemenuhan kesehatan.

Kematian akibat Penyakit Tidak Menular (PTM) diperkirakan akan terus meningkat di seluruh dunia, peningkatan terbesar akan terjadi di negara-negara menengah dan miskin. Lebih dari dua pertiga (70\%) dari populasi global akan meninggal akibat penyakit tidak menular seperti kanker, penyakit jantung, hipertensi, stroke dan diabetes. Menurut perkiraan WHO, kematian akibat PTM akan meningkat 15\% secara global (sebanyak 44 juta kematian) antara tahun 2010 sampai tahun 2030. Wilayah yang akan mengalami peningkatan paling besar sebesar lebih dari 20\% terjadi di wilayah Afrika, Asia Tenggara dan Mediterania Timur (WHO, 2011).

Indonesia merupakan salah satu negara yang telah menetapkan program nasional untuk menanggulangi masalah PTM melalui program Posbindu PTM (Pos Pembinaan Terpadu). Posbindu dilakukan untuk seluruh masyarakat yang berusia 15 tahun ke atas dengan pelaksana masyarakat dan dibantu oleh petugas puskesmas setempat (Depkes, 2013). Dilakukan secara berkala dengan menggunakan sistem 5 meja, yaitu pendaftaran; wawancara terarah; pengukuran TB, BB, IMT, Lingkar perut dan analisa lemak tubuh; pengukuran tekanan darah gula, kolesterol total dan trigliserida darah, Inspeksi Visual Asam Asetat (IVA), kadar alkohol pernafasan dan tes amfetamin urin; serta konseling, edukasi dan tindak lanjut lainnya (Kemenkes RI, 2014).

Puskesmas yang membina Posbindu PTM di Indonesia sebesar 49,3\%, tertinggi di Provinsi Bangka Belitung (100\%), DIY (90,1\%), dan Jawa Timur (87,7\%). Persentase pengunjung Posbindu PTM dan puskesmas dengan tekanan darah tinggi dari hasil pengukuran tekanan darah yang tercatat di Pos Pembinaan Terpadu (Posbindu) PTM dan puskesmas menurut jenis kelamin, pada laki- laki sebesar 48,6\% sedangkan pada perempuan 43,7\%, dan persentase pengunjung Posbindu PTM dan puskesmas dengan tekanan darah tinggi menurut kelompok umur sebagian besar pada kelompok usia lanjut (umur _60 tahun) sebesar 63,9\%, Menurut provinsi persentase tekanan darah tinggi tertinggi di Provinsi Jawa Barat (65,5\%), Jawa Tengah (61,6\%), dan Banten (60,1\%) (Kemenkes RI,2016).

Posbindu PTM merupakan salah satu upaya kesehatan bersumber daya masyarakat (UKBM) yang berorientasi kepada upaya promotif dan preventif dalam pengendalian PTM dengan melibatkan masyarakat mulai dari perencanaan, pelaksanaan dan monitoringevaluasi. Posbindu PTM berkembang di bawah pembinaan puskesmas dan merupakan salah satu tuntutan dari Undang-Undang Kesehatan RI Nomor 36 Tahun 2009 Bab X Pasal 158 bahwa pemerintah, pemerintah daerah, dan masyarakat melakukan upaya pencegahan.

Hasil penelitian yang dilakukan Ayu (2018) dalam menganalisis pelaksanaan program pos pembinaan terpadu penyakit tidak menular di wilayah kerja Puskesmas Kota Matsum tahun 2018 dapat disimpulkan bahwa program Posbindu PTM di wilayah kerja Puskesmas Kota Matsum belum maksimal, maka diharapkan kepada pihak Dinas Kesehatan Kota Medan melengkapi sarana dan prasarana serta memberikan pelatihan yang rutin bagi para kader. Diharapkan adanya kerjasama dan koordinasi dengan berbagai pihak dalam pelaksanaan Posbindu PTM dan diharapkan meningkatkan kualitas maupun kuantitas dari kegiatan posbindu. 
Hasil penelitian Parinduri (2015) menunjukkan bahwa pelaksanaan program Posbindu PTM memperoleh dukungan dari masyarakat sendiri dan telah berjalan dengan baik. Hal ini ditunjukkan melalui adanya sarana dan prasarana yang mendukung, pendanaan yang memadai melalui mitra dan kerjasama puskesmas dengan lembaga lain, adanya partisipasi dan sambutan baik dari masyarakat dan petugas pelaksana yang bertanggung jawab. Meskipun demikian, masih terdapat beberapa hal yang menjadi bahan evaluasi yang perlu ditingkatkan untuk pencapaian output dari pelaksanaan posbindu PTM dalam deteksi dini dan mencegah komplikasi diabetes melitus. Monitoring terhadap pelaksanaan program menjadi perhatian penting dalam menjaga keberlanjutan pelaksanaan program.

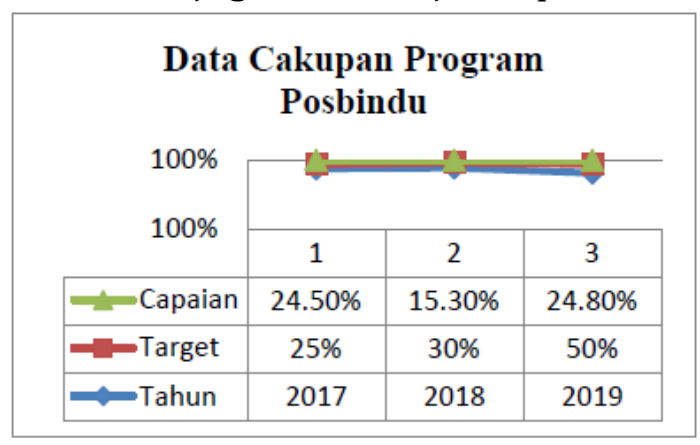

\section{Gambar 1 Diagram Data Cakupan Program Posbindu Di Puskesmas Cibungbulang}

Berdasarkan diagram diatas dapat dijelaskan bahwa di Puskesmas Cibungbulang Kabupaten Bogor menunjukkan pada tahun 2017 cakupan Program Posbindu yang di dapat sebesar 24,5\% dengan target sebesar 25\% lalu pada tahun 2018 cakupan Program Posbindu yang di dapat sebesar 15,3\% dengan target sebesar 30\% dan pada tahun 2019 cakupan Program Posbindu yang di dapat sebesar 24,8 \% dengan target sebesar 50\% yang telah ditentukan dengan itu pada tahun 2017 sampai dengan tahun 2019 laporan kunjungan program posbindu tidak mencapai target yang telah tentukan.

Karena terjadinya pandemi coronavirus disease 19 (Covid-19) di tahun 2020, maka dari itu peneliti ingin mengulas lebih dalam dan mengetahui perbedaaan pelayanan Program Pos Pembinaan Terpadu Penyakit Tidak Menular sebelum dan sesudah terjadinya pandemi coronavirus disease 19 ( Covid-19) di Wilayah Kerja Puskesmas Cibungbulang Tahun 20192020 .

\section{METODE PENELITIAN}

Penelitian ini dilakukan di Puskesmas Cibungbulang, yang dilaksanakan pada bulan Juli Agustus 2020. Jenis penelitian ini menggunakan penelitian deskriptif dengan pendekatan kualitatif yang di dapatkan dengan metode wawancara mendalam, observasi, dan telaah dokumen. Teknik pengumpulan data meliputi data primer melalui wawancara mendalam serta observasi dan data sekunder melalui dokumen - dokumen. Informan penelitian terdiri dari 11 orang yaitu 1 kepala puskesmas, 1 penanggung jawab program, 1 pelaksana program, 4 kader dan 4 peserta posbindu PTM. 


\section{HASIL PENELITIAN}

\section{Perencanaan}

Berdasarkan hasil wawancara yang telah dilakukan bahwa perencanaan terkait Posbindu PTM di Wilayah Kerja Puskesmas Cibungbulang dilakukan oleh 2 orang petugas puskesmas dan 5 orang kader di setiap desanya dan dinyatakan cukup. Berikut hasil kutipan wawancara yang telah dilakukan:

"Secara teknis sudah mencukupi....yang pasti yang bertanggung kepala puskesmas dibawahnya ada petugas program posbindunya serta kebawahnya lagi perawat serta kader-kader, jumlah pastinya mungkin lebih dari 5 orang ya " (Informan 9)

Berdasarkan hasil wawancara yang telah dilakukan bahwa perencanaan terkait Posbindu PTM di Wilayah Kerja Puskesmas Cibungbulang dinyatakan adanya tempat pemeriksaan, meja, kursi, buku KMS, tensimeter , alat ukur lingkar perut, alat ukur tinggi badan dan alat ukur gula darah dan kolesterol. Berikut hasil kutipan wawancara yang telah dilakukan :

"Ya saran prasarannya berarti... ada tempat pemeriksaanya di lengkapi dengan alat tensi, alat timbang badan, pengukuran, dan juga alat-alat laboratorium sederhana seperti cek gula darah atau cek kolesterol yang dibutuhkan pada pasien-pasien yang memang sudah berusia lanjut" (Informan 9)

Berdasarkan hasil wawancara yang telah dilakukan bahwa dalam perencanaan posbindu PTM di Puskesmas Cibungbulang terdiri dari dana Bantuan Operasional Kesehatan (BOK) dan Anggaran Pendapatan dan Belanja Daerah (APBD) sedangkan untuk kader bersumber dari Anggaran Dana Desa (ADD) dan ada salah satu posbindu yang tidak memakai dana dari puskesmas dana tersebut berasal dari yayasan baitul mal (YBM) dan dana sehat dari peserta posbindu PTM sebesar 1000- 5000 rupiah. Berikut hasil kutipan wawancara yang telah dilakukan:

"Sumber biayanya pake APBD, BOK" (Informan 10)

"Alhamdulillah kita dapat bantuan dari ybm pln ybm itu artinya dari singkatan yayasan baitul mal eee... Jadi yang merekrut uang zakat karyawan pln yaitu namanya ybm dari pln eeee.... Pajajaran bogor" (Informan 1)

"Dari desa dikasih berupa bantuan operasional penyelenggaraan untuk beli obat dan dana triwulan dari ADD kalo dari puskesmas di kasih untuk pmt (makanan lansia) sama uang keropok peserta seikhlasnya" (Informan 7)

Berdasarkan hasil wawancara dan observasi dengan informan yang ditemukan informasi terkait pedoman dan SOP (Standar Operasional Prosedur) ada dan sesuai dengan SOP Dinas Kesehatan Kabupaten yaitu menggunakan petunjuk teknis program posbindu PTM terkait kegiatan posbindu PTM tersebut. Berikut hasil kutipan wawancara yang telah dilakukan:

"Pedomannya itu kita mengikuti sesuai dengan SOP dari dinas Kesehatan semacam Juknis Posbindu PTM Kementerian Kesehatan RI " (Informan 11)

Berdasarkan hasil wawancara yang telah dilakukan bahwa kendala atau hambatan yang ditemukan terkait perencanaan kegiatan posbindu yaitu terkait dengan penjadwalan dan 
pandemi seperti sekarang ini. Berikut hasil kutipan wawancara yang telah dilakukan:

"Ya salah yang menghambat seperti sekarang nih ada pandemi seperti ini termasuk salah satu kendala untuk bisa terus melaksanakan kegiatanya tersebut sesuai dengan jadwal"

(Informan 9)

"Kadang kita suka bentrok jadwalnya dengan posyandu karena gedungnya itu kita gabung dengan posyandu jadi kita suka ngalah mundur atau maju gitu " (Informan 11)

Berdasarkan hasil wawancara yang telah dilakukan bahwa strategi yang dilakukan terkait dengan kendala-kendala perencanaan kegiatan posbindu tersebut yaitu dengan pengaturan jadwal kembali dan menerapkan aturan sesuai dengan SoPnya tersebut. Berikut hasil kutipan wawancara yang telah dilakukan:

"Strategi yang dilakukan ya dilihat dari permasalahannya ,apabila permasalahannya terdapat dari teknis ya itu bisa di lakukan hal-hal menunjang secara aturan dan alur-alur yang dilaksanakan secara posbindunya kalo berhubungan dengan sop ya kita melaksanakan sesuai dengan protokol kesehatan Covid-19 kalau memang sudah tidak bisa kita stop dan kalo pun terpaksa bisa dari online gitu " (Informan 9)

"Kalo strateginya itu biasanya ya kita cari jadwal lagi di majuin atau di mundurin" (Informan 11)

\section{Pengorganisasian}

Berdasarkan hasil wawancara yang telah dilakukan pihak-pihak yang bekerjasama dengan puskesmas dalam pelaksanaan kegiatan Posbindu PTM di Wilayah Kerja Puskesmas Cibungbulang Desa Cimanggu 2, Desa Cimanggu 1 dan Desa Leuweung Kolot yaitu pihak Kecamatan, Pihak Desa, Pihak RT dan RW dan Pihak Kader Posbindu Desa tersebut. Berikut hasil kutipan wawancara yang telah dilakukan:

"Ya udah pasti dari puskesmasnya ya,ada juga kader-kadernya, selain itu juga ada dari pihak desa dan ada juga dari pihak kecamatan jadi terintegrasi karena posbindu ini komplek jadi bekerjasamanya menyeluruh semua lintas sektor yang ada di puskesmas cibungbulangnya" (Informan 9)

Berdasarkan hasil wawancara yang telah dilakukan bentuk kerjasama pihak-pihak dengan puskesmas dalam pelaksanaan kegiatan Posbindu PTM yaitu dengan memberikan informasi terkait kegiatan yang akan dilakukan di rapat lokakarya, mingguan, triwulan serta rapat tahunan Berikut hasil kutipan wawancara yang telah dilakukan:

"Ya dengan adanya program posbindu PTM ini kita sering melakukan pertemuan dengan mereka sebelum Covid ya, nanti kita dengan pihak kecamatan itu bersatu dalam program dengan dinas kesehatan dan pihak desa di situ di remukan program-program yang harus berjalan itu seperti apa, karena banyak juga permasalahan yang harus diketahui oleh kecamatan biasanya kita bertemu di rapat mingguan Nah ada triwulan juga bahkan bukan hanya triwulan ada pertemuan tahunan biasanya pada awal tahun kita sudah membicarakan program-program apa saja sih yang akan kita laksanakan secara menyeluruh secara satu tahun kedepan di pihak kecamatan yang diikuti oleh pihak desa yang ada di kecamatan" (Informan 9) 


\section{Pelaksanaan}

\section{1) Input Pelaksanaan}

Berdasarkan hasil wawancara peran SDM dalam program posbindu PTM sebelum terjadinya pandemi Covid-19 untuk kader perannya meliputi kegiatan pendaftaran, pengukuran, pelaporan dan pencatatan hasil kegiatan posbindu PTM ke puskesmas dan untuk petugas puskesmas meliputi pemeriksaan dan konseling peserta posbindu tersebut sedangkan setelah adanya pandemi Covid-19 kegiatan posbindu ditiadakan hanya melalui online saja dengan kader tetapi ada 2 posbindu yang sudah mengadakan kembali kegiatan posbindu dengan metode door to door dan metode seperti biasanya hanya saja untuk penimbangan, pengukuran dan penyuluhan saja untuk pemeriksaan oleh petugas puskesmas itu tidak ada akan tetapi itu pun sudah tidak boleh diadakan kembali untuk bulan depannya sampai waktu yang tidak bisa ditentukan . Berikut hasil kutipan wawancara:

"Kalo sebelum pandemi kita kegiatannya full gitu ya berkumpul dengan melaksanakan sesuai dengan SOPnya. Kalo setelah pandemi kegiatan itu kita tidak ada kegiatan yang berkumpul... hmm tapi kemari ada yang sudah mengadain seperti door to door itu kesinikesininya itu juga hanya semacam tensi nimbang saja ...eee dan ada juga si kemarin yang mengadakan juga tapi bukan memakai metode door to door tapi seperti biasa saja tapi tidak ada pemeriksan merek hanya semacam timbang dan tensi juga dan eee... sama ada penyuluhan dari kami petugas puskesmas tetapi itu pun sudah tidak di bolehkan lagi sama pihak puskesmasnya untuk bulan depannya dan ga tau sampai kapan mungkin sampai waktu yang tidak bisa ditentukan " (Informan 10)

Berdasarkan hasil wawancara tentang standar kompetensi yang harus di miliki oleh pelaksana program posbindu yaitu sudah mengikuti pelatihan sedangkan untuk kader harus mengetahui tentang wawasan posbindu faktor resikonya dan setelah adanya pandemi Covid19 semua petugas pelaksana baik kader atau petugas puskesmasnya harus mengetahui tentang wawasan posbindu dan memahami protokol kesehatannya yang sudah ditentukan . Berikut hasil kutipan wawancara:

"Kalo untuk petugasnya itu harus sudah mengikuti pelatihan gitu dan untuk kadernya ya harus mengetahui tentang wawasan posbindu faktor resikonya gitu dan kalo setelah Covid itu sama saja semua petugas pelaksana baik kader atau petugas puskesmasnya ya harus mengetahui tentang wawasan posbindunya dan memahami protokol kesehatannya yang sudah ditentukan itu" (Informan 11)

Berdasarkan hasil wawancara yang telah dilakukan bahwa tugas kader dalam pelaksanaan kegiatan posbindu PTM meliputi menginfokan terkait kegiatan, mengisi daftar hadir, mengisi buku KMS peserta, menimbang, mengukur, membagikan makanan dan mencatat laporan. Berikut hasil kutipan wawancara yang telah dilakukan:

"Yaa ngisi apa namanya... daftar hadir. penimbangan ,ngukur-ngukur sama nulis laporan ngisi buku KMS sama ngasih senam ibu-ibunya samaa eee... ngasih snack buat ibu-ibunya sama suka ngumumin mau ada posbindu" (Informan 5) 
Berdasarkan hasil wawancara yang telah dilakukan bahwa SDM yang bertugas pada tahapan pendaftaran di 4 posbindu PTM sebelum terjadinya pandemi Covid-19 yang meliputi pengisian buku daftar kehadiran, pencatan identitas diri seperti nama, usia, alamat RT/RW dan pencarian buku KMS untuk peserta posbindu PTM sedangkan setelah adanya Covid-19 tahap pendaftaran tidak ada perbedaan sama saja hanya saja mengikuti protokol kesehatan dengan menggunakan masker, mencuci tangan dan mengecek suhu terlebih dahulu tetapi ada 2 pos posbindu yang mengadakan posbindu yang satu dengan menggunakan metode door to door dan tidak ada tahapan pendaftaran dan yang posbindu kedua sama saja tidak ada perbedaan untuk tahap pendaftaran. Berikut hasil kutipan wawancara yang telah dilakukan:

"Itu yang pertama ngisi daftar hadir ada nama,alamat,terus nyari buku kms pesertanya deh kalo udah di timbang laporin lagi ke bagian pendaftarannya terus keluhan juga... eee neng pas udah ada Covid mah kemarin kan ibu sempet ngadain tapi kita door too door bukan ngadain di tempat gitu jadi kita yang ngunjungin dan gada pendaftarannya pas Covid gini mah" (Informan 5)

"Paling yang megang pendaftaran mah kaya nulis nama gitu,kemaren sempet ngadain kan dan tidak ada perbedaan setelah ada corona juga paling sebelum masuk di cek suhu sama suruh cuci tangan sama pake eee.... Masker paling itu bedanya " (Informan 7)

Berdasarkan hasil wawancara yang telah dilakukan bahwa SDM yang bertugas pada tahapan wawancara di 3 posbindu PTM sebelum dan sesudah terjadinya pandemi Covid-19 antara lain wawancara pola makanan hidup sehat, pola hidup sehat dan pencegahan penyakit hipertensi. Berikut hasil kutipan wawancara yang telah dilakukan:

"Paling itu mah apa namanya yang megang wawancara suka nanya-nanya gitu apa keluhan lansianya paling itu aja eh... sama suka ngasih tau makanan yang sehat deh, sama aja tidak ada perbedaan sih pas udah ada Covid juga" (Informan 7)

Salah satu informan menyatakan bahwa tidak ada wawancara Kesehatan tersebut. Berikut hasil kutipan wawancara yang telah dilakukan:

"Ga ada teh ga ada wawancara sama kader" (Informan 3)

Berdasarkan hasil wawancara yang telah dilakukan bahwa SDM yang bertugas pada tahapan pengukuran di 4 posbindu PTM sebelum terjadinya pandemi Covid-19 meliputi kegiatan pengukuran berat badan, tinggi badan dan tensi sedangkan setelah adanya Covid-19 tahap pengukuran ini sama saja tidak ada perbedaan hanya saja berjarak dan mengikuti protokol Kesehatan yang sudah ditentukan. Berikut hasil kutipan wawancara yang telah dilakukan:

"Kalo bagian pengukuran ya

pengukuran, kadernya ngukur tinggi badan, berat badan gitu, iya sama aja sih ga ada perbedaan setelah ada Covid juga eee... ya paling berjarak aja si " (Informan 7)

Berdasarkan hasil wawancara yang telah dilakukan bahwa SDM yang bertugas pada tahapan pemeriksaan di 4 posbindu PTM sebelum adanya pandemi Covid-19 meliputi kegiatan pemeriksaan gula darah,kolesterol dan dilakukannya oleh petugas puskesmas sedangkan setelah adanya pandemi Covid-19 tahap pemeriksaan ini sama saja tidak ada perbedaan 
hanya saja ada 2 posbindu yang mengadakan posbindu dengan seperti biasa dan posbindu dengan metode door to door tetapi tidak ada pemeriksaan oleh petugas puskesmas akan tetapi itu pun sudah tidak boleh diadakan kembali bulan depannya sampai waktu yang tidak bisa ditentukan. Berikut hasil kutipan wawancara yang telah dilakukan:

"Pemeriksaan mah sama petugas puskesmas dokter gitu sama suka bu hj nina juga, pas kemarin setelah Covid pas door to door mah ga ada pemeriksaan cuman kita aja kadernya " (Informan 5)

"Pemeriksaan mah biasanya sama petugas puskesmas, setelah ada Covid kemarin sempet posbindu lagi tapi sekarang udah ga boleh lagi gatau sampe kapan haha... terus pas kemarin ga ada pemeriksaan cuman penyuluhan aja dari petugas mah" (informan 7)

Berdasarkan hasil wawancara yang telah dilakukan bahwa SDM yang bertugas pada tahapan identifikasi faktor resiko di 4 posbindu PTM sebelum adanya pandemi Covid-19 dilakukannya oleh petugas puskesmas sedangkan setelah adanya Covid-19 tahap pada tahapan identifikasi faktor resiko ini sama saja tidak ada perbedaan hanya saja ada posbindu yang melakukan kegiatan posbindu seperti biasa dan posbindu metode door to door tetapi tidak ada pemeriksaan oleh petugas puskesmas tersebut. Berikut hasil kutipan wawancara yang telah dilakukan:

"Eee... konseling ini dilakukan oleh tim medis dari puskesmasnya dan tidak ada perbedaan setelah ada Covid juga sama saja sama tim medis puskesmas" (Informan 1)

Berdasarkan hasil wawancara yang telah dilakukan bahwa ketersediaan sarana dan prasarana dalam kegiatan posbindu PTM sebelum dan sesudah terjadinya pandemi Covid-19 masih kurang lengkap. Berikut hasil kutipan wawancara yang telah dilakukan:

"Masih kurang si sepertinya karena belum semua posbindu mempunyai alat pengukur kolesterol atau asam urat, dan setelah Covid itu belum tau mungkin masih kurang dan harus dipersiapkan lagi nanti sama kadernya kaya pencuci tangan masker dan pengecekan suhu tersebut" (Informan 10)

Berdasarkan hasil wawancara yang telah dilakukan bahwa biaya yang diperlukan untuk penyelenggaraan posbindu PTM di Wilayah Kerja Puskesmas Cibungbulang sebelum terjadinya pandemi Covid-19 terdiri dari pembiayaan untuk transportasi, stik untuk alat pengukuran kolesterol maupun gula darah, pembelian obat, fotocopy, pembelian ATK dan makanan sedangkan setelah adanya pandemi Covid-19 tidak ada perbedaan untuk biaya yang diperlukan tersebut. Berikut hasil wawancara yang telah dilakukan:

"Makanan sama stik aja si , oh terus pas udah ada Covid mah makanan aja kan kemaringa ada pemeriksaan tapi kalo nanti udah berjalan seperti biasa mah sama aja biaya yang diperlukan buat makanan sama stik kemarin mah kan gara-gara masih was-was dan sekarang juga kan ga boleh lagi" (Informan 7)

Berdasarkan hasil wawancara yang telah dilakukan bahwa biaya yang keluarkan oleh peserta pada pelaksanaan kegiatan posbindu PTM di Wilayah Kerja Puskesmas Cibungbulang sebelum dan sesudah terjadinya pandemi Covid-19 yaitu gratis atau hanya seikhlasnya dan untuk yang 
ingin pengecekan kolesterol, asam urat atau gula darah itu bayar . Berikut hasil wawancara yang telah dilakukan:

"Paling itu doangan keropak seikhlasnya,terus kalo mau cek kolesterol bayar 10.000 kalo asam urat 5.000 terus sama gula darah 10.000, sama aja teh gada perbedaanya pas udah ada corona juga" (Informan 8).

Berdasarkan hasil wawancara yang telah dilakukan bahwa dana untuk penyelenggaraan posbindu sebelum dan sesudah terjadinya pandemi Covid-19 belum sesuai standar minimal . Berikut hasil kutipan wawancara yang telah dilakukan:

"Masih ragu juga sih belum mencukupi si karena kan kita harus mengajukan dulu pendanaan tersebut ke bok nya itu,kalo setelah Covid belum tau sih ya" (Informan 11)

Berdasarkan hasil wawancara yang dilakukan bahwa bentuk pelatihan yang diadakan oleh Puskesmas Cibungbulang sebelum terjadinya pandemi Covid-19 seperti pelatihan TLT, OJT dan workshop tentang posbindu PTM sedangkan setelah terjadinya pandemi Covid-19 hanya ada webinar untuk menambah pengetahuan. Berikut hasil kutipan wawancara yang telah dilakukan:

"Bentuk pelatihannya ya terkait dengan posbindu aja sih gitu aja dan setelah Covid kemarin ada webinar hanya untuk menambah pengetahuan saja tentang posbindu" (Informan 10)

Berdasarkan hasil wawancara yang telah dilakukan bahwa yang mendapat pelatihan terkait program Posbindu PTM sebelum terjadinya pandemi Covid-19 yaitu penanggung jawab program posbindu PTM, Pelaksana program posbindu dan kader sedangkan sesudah terjadinya pandemi Covid-19 belum ada pelatihan lagi hanya webinar saja untuk petugas puskesmasnya. Berikut hasil kutipan wawancara yang telah dilakukan:

"Penanggung jawab program posbindunya, pelaksana program posbindunya dan kader" (Informan 9)

Berdasarkan hasil wawancara yang telah dilakukan terkait terakhir mengadakan pelatihan Posbindu PTM yaitu pada tahun 2019. Berikut hasil kutipan wawancara yang telah dilakukan:

“Terakhir tahun 2019 " (Informan 11)

Berdasarkan hasil wawancara yang dilakukan bahwa kader di 4 posbindu PTM di Puskesmas Cibungbulang sebelum terjadinya pandemi Covid-19 telah mendapatkan pelatihan tentang posbindu PTM walaupun tidak semua mendapatkan pelatihan. Pelatihan tersebut mengenai faktor risiko,dampak dan cara pengendalian PTM di Puskesmas Cibungbulang tetapi ada salah satu kader yang sudah mengikuti pelatihan tetapi belum diberikan pengetahuan yang cukup sedangkan setelah terjadinya pandemi Covid-19 belum ada pelatihan kembali. Berikut hasil kutipan wawancara yang telah dilakukan:

"Pernah sekali aja itu di puskesmas itu sama bu hj nina,sebenarnya ini saya ini merangka rangka haha belum ada hanya mengikuti jalur orang lain nahh kita mencari sendiri searching searching gitu dan setelah ada Covid juga saya nerawang-nerawang aja saya 
suka baca-baca terus suka liat di tv gini-gini saya terapkan dan suka searching juga" (Informan 1)

\section{2) Tahap Layanan}

Berdasarkan hasil wawancara yang telah dilakukan bahwa jadwal pelaksanaan kegiatan posbindu PTM di setiap RW berbeda-beda, sesuai dengan kesepakatan bersama. Posbindu PTM di Wilayah Kerja Puskesmas Cibungbulang rata-rata telah dilaksanakan lebih dari satu tahun. Berikut hasil kutipan wawancara yang telah dilakukan :

“Sebulan sekali setiap pos itu jadi gimana perjadwalnya aja " (Informan 10)

Berdasarkan hasil observasi yang dilakukan bahwa ada beberapa posbindu yang sudah menerapkan sistem 5 tetapi ada salah satu posbindu yang terkadang menerapkan dan terkadang tidak dan ada salah satu pula posbindu yang menggunakan sistem 5 meja tetapi tidak berurutan tahap layanannya yaitu pada posbindu satu melakukan tahap pertama pendaftaran, tahap kedua wawancara oleh kader tahap ketiga pengukuran tinggi badan dan berat badan tahap keempat pemeriksaan tahap kelima konseling atau identifikasi faktor, pada posbindu dua sistem 5 meja terkadang berjalan terkadang tidak tahap pertama pendaftaran tahap kedua pengukuran tahap ketiga pemeriksaan, pada posbindu ketiga berjalan tetapi tidak berurutan tahapannya pertama pendaftaran, tahap kedua pengukuran,tahap ketiga wawancara,tahap keempat pemeriksaan tahap kelima identifikasi faktor atau konseling, pada posbindu keempat melakukan tahap pertama pendaftaran tahap kedua wawancara tahap ketiga pengukuran tahap keempat pemeriksaan tahap kelima konseling atau identifikasi faktor. Berdasarkan hasil observasi dapat disimpulkan 2 posbindu melakukan sistem 5 meja dengan sesuai petunjuk teknis sedangkan 2 posbindu lain tidak sesuai dengan tahapan petunjuk teknis. Berdasarkan hasil wawancara yang telah dilakukan bahwa sistem 5 meja sebelum terjadinya pandemi Covid-19 sudah diterapkan atau dilaksanakan walaupun ada beberapa tahap yang tidak berurutan dan terkadang tahap tersebut berjalan dan tidak sedangkan setelah adanya Covid-19 posbindu yang melakukan kegiatan tersebut tidak berjalan sesuai dengan tahapannya.Berikut hasil kutipan wawancara yang telah dilakukan:

"Iya berjalan sudah dilaksanakan" (Informan 1)

"Kadang berjalan kadang engga teh" (Informan 3)

"Berjalan tapi ga berurutan neng" (Informan 5)

Berdasarkan hasil wawancara yang telah dilakukan bahwa alur pelaksanaan yang dilakukan di posbindu PTM sebelum terjadinya Covid-19 antara lain tahap pertama peserta melakukan pendaftaran, tahap kedua wawancara, tahap ketiga penimbangan pengukuran berat badan, lingkar badan, dan tensi, tahap empat pemeriksaan kolesterol gula darah jika ada, dan tahap kelima identifikasi faktor atau konseling sedangkan setelah terjadinya Covid-19 tahapannya itu sama tidak ada perbedaan hanya saja mengikuti protokol kesehatannya tersebut. Berikut hasil kutipan wawancara yang telah dilakukan:

"Pendaftaran terus mencatat di buku register sama di masukin ke buku kms setelah itu terus ada wawancara atau penyuluhan sama kader sebelum pemeriksaan baru pengukuran gitu terus senam lalu pemeriksaan nah meja terakhirnya baru konseling atau 
suka penyuluhan sama petugas puskesmas nya gitu dan setelah Covid ini nanti jika sudah di adakan kegiatan lagi paling sama aja kita sesuaikan dengan prosedur atau protokol kesehatannya saja" (Informan 10)

\section{3) Hambatan dan Strategi Pelaksanaan}

Berdasarkan hasil wawancara yang telah dilakukan bahwa kendala atau hambatan yang ditemukan terkait dengan SDM Pelaksanaan kegiatan posbindu sebelum terjadinya pandemi Covid-19 yang ada di puskesmas cibungbulang terkait dengan petugas puskesmasnya tidak ada hambatan dan kendala sedangkan untuk kader terdapat hambatan seperti telat memberikan laporan ke puskesmas dan setelah adanya Covid-19 ini kendala dan hambatan terkait SDM belum terlihat. Berikut hasil kutipan wawancara yang telah dilakukan:

"Kalau kader kendalanya itu paling ke laporan aja kalau kerja di lapangannya mah kaderkader udah pada bagus sih mereka ga leha-leha serius gitu lancar-lancar aja,kalo petugas puskesmas mah ga ada, kalo setelah Covid mah belum keliatan sih " (Informan 10)

Berdasarkan hasil wawancara yang telah dilakukan bahwa kendala atau hambatan yang ditemukan oleh kader terkait dengan Pelaksanaan kegiatan posbindu yang ada di puskesmas cibungbulang sebelum terjadinya pandemi Covid-19 meliputi peserta yang harus dirujuk, dan partisipasi peserta tidak konsisten sedangkan kendala atau hambatan yang ditemukan oleh kader setelah adanya Covid-19 meliputi peserta yang tidak mempunyai masker, pencuci tangan dan peserta susah untuk diberitahu. Berikut hasil kutipan wawancara yang telah dilakukan:

"Kadang kendalanya tuh ibu- ibunya2 kadang bulan ini dateng bulan ini engga padahal kita udah ngasih tau ngumumin gitu paling itu aja,kalo setelah Covid mah gada kendala sih teh kan baru sekali aja kemarin itu juga door to door eee... tapi aga ribet juga sih kerjanya jadi harus ekstra gitu ya" (Informan 5)

Berdasarkan hasil wawancara yang telah dilakukan bahwa terdapat kendala dan hambatan sebelum dan sesudah terjadinya pandemi Covid-19 terkait sarana dan prasarana dalam kegiatan posbindu PTM seperti ada beberapa posbindu yang tidak memiliki alat pengukuran cek kolesterol,gula darah, stik kolesterol dan gula darah, pengukuran lingkar perut, masker, pengecekan suhu dan pencuci tangan. Berikut hasil kutipan wawancara yang telah dilakukan:

"Banyak tehyang tadi ibu bilang ga ada cek gula darah kolesterol terus eee... Asam urat sama eee.... Pengukuran perut ya, setelah ada si Covid mah paling itu ya kita harus nyiapin cuci tangan soalnya belum ada kan yaa "(Informan 3)

Berdasarkan hasil wawancara yang telah dilakukan bahwa saran dan masukan peserta terkait sarana prasarana terhadap kegiatan posbindu PTM di Puskesmas Cibungbulang sebelum dan sesudah terjadinya pandemi Covid-19 meliputi tempat pemeriksaan, alat pengukuran kolesterol gula darah, dan masker. Berikut hasil kutipan wawancara yang telah dilakukan:

"Mau buat cek kolesterol terus gula darah neng belum ada kan" (Informan 6) 
Berdasarkan hasil wawancara yang telah dilakukan bahwa kendala atau hambatan yang ditemukan terkait pembiayaan kegiatan posbindu sebelum terjadinya pandemi Covid-19 yaitu terkait dengan masih kurangnya biaya untuk pembelian stik dan obat sedangkan sesudah terjadinya pandemi Covid-19 lebih banyak mengeluarkan terkait masker dan pencuci tangan . Berikut hasil kutipan wawancara yang telah dilakukan:

"Ya paling itu kita buat beli stik kendala buat biaya mah,pas udah ada Covid mah sama aja si stik juga eh .... iya itu biaya buat beli pencuci tangan terus apa itu namanya masker ya" (Informan 7)

Berdasarkan hasil wawancara yang telah dilakukan bahwa strategi yang dilakukan terkait dengan kendala- kendala pembiayaan kegiatan posbindu tersebut sebelum dan sesudah terjadinya pandemi Covid-19 yaitu dengan menggunakan uang kas kader, uang seikhlasnya peserta dan biaya pembayaran pengukuran kolesterol atau gula darah peserta . Berikut hasil kutipan wawancara yang telah dilakukan:

"Solusinya paling kita ambil aja dari uang kas yang dari triwulan kader suka di potong per triwulannya perkadernya 50.00 ribu sama paling dari uang keropok aja sih" (Informan

5)

Berdasarkan hasil wawancara yang telah dilakukan bahwa kendala atau hambatan yang ditemukan terkait pelatihan kegiatan posbindu sebelum terjadinya pandemi Covid-19 tidak ada kendala atau hambatan sedangkan setelah terjadinya pandemi Covid-19 kendala atau hambatannya yaitu kurang fokus karena melalui zoom meeting. Berikut hasil kutipan wawancara yang telah dilakukan:

"Tidak ada kendala sih,paling setelah Covid ini pas webinar ini jadi kurang greget gitu kurang fokus gitu karena kita terbiasa dengan jarak jauh lebih enak tatap muka" (Informan 10)

\section{Pengawasan}

Berdasarkan hasil wawancara yang telah dilakukan bahwa proses rujukan sebelum dan sesudah terjadinya pandemi Covid-19 oleh petugas puskesmas itu sama saja hanya diberikan surat rujukan kepada peserta untuk peserta datang ke puskesmas langsung. Berikut hasil kutipan wawancara yang telah dilakukan:

"Untuk rujukan itu kalau kita menemukan pasien kalo yang gula darahnya tinggi kondisinya tidak baik baru kita kasih surat rujukan suruh langsung ke puskesmas dan setelah Covid mah belum ada sih ya itu kan belum ada kegiatan" (Informan 10)

Berdasarkan hasil wawancara yang telah dilakukan bahwa pencatatan dan pelaporan hasil kegiatan posbindu di 4 Posbindu PTM ini berbentuk buku kohort pertiap posbindu yang isinya terdiri dari nama,alamat,umur, keluhan penyakit dan data kunjung peserta. Berikut hasil kutipan wawancara yang telah dilakukan:

"Hanya dari buku kohort saja isinya itu ada nama ,umur,alamat,terus kegiatan yang sudah dilaksanakan lalu keluhan pasien gitu”(Informan 10) 
Berdasarkan hasil wawancara yang telah dilakukan bahwa bentuk monitoring yang dilakukan oleh pihak puskesmas seperti dalam lokakarya mini, lokakarya bulanan dan dilihat dari hasil laporan kader setiap bulannya dan membuat laporan untuk dilaporkan ke dinas setelah itu terdapat pertemuan untuk pembahasan evaluasi laporan tersebut. Berikut hasil kutipan wawancara yang telah dilakukan:

"Kita buat laporan sebulan sekali untuk ke dinas ,bentuk evaluasinya itu kita lapor ke dinas lalu setelah lapor baru ada pertemuan dan itu di bahas evaluasi laporan itu seperti itu sih" (Informan 10)

Berdasarkan hasil wawancara yang telah dilakukan bahwa peran pihak Dinas Kesehatan terkait pengawasan kegiatan posbindu PTM yaitu hanya dengan melihat laporan setiap bulannya . Berikut hasil kutipan wawancara yang telah dilakukan:

"Untuk Dinas Kesehatan ini kan menerima laporan setiap puskesmas setelah itu mereka nanti evaluasi di monitoring dulu gitu sama mereka baru di evaluasi setelah itu " (Informan 10)

\section{PEMBAHASAN}

\section{Perencanaan}

Perencanaan yaitu sebagai dasar pemikiran dari tujuan dan penyusunan langkahlangkah yang akan dipakai untuk mencapai tujuan. Merencanakan berarti mempersiapkan segala kebutuhan, memperhitungkan matang-matang apa saja yang menjadi kendala, dan merumuskan bentuk pelaksanaan kegiatan yang bermaksud untuk mencapai tujuan (Terry,2019).

Berdasarkan hasil wawancara yang telah dilakukan bahwa perencanaan terkait Posbindu PTM di Wilayah Kerja Puskesmas Cibungbulang dilakukan oleh 2 orang petugas puskesmas dan 5 orang kader di setiap desanya dan dinyatakan cukup.

Hal ini sejalan dengan Juknis Kemenkes (2012), bahwa semua pegawai puskesmas wajib berpartisipasi dalam kegiatan Posbindu PTM. Penanggung jawab Posbindu PTM merupakan koordinator dalam penyelenggaraan kegiatan Posbindu PTM dan berdasarkan penelitian Saputra, dkk (2017), berdasarkan kuantitasnya, jumlah SDM yang dibutuhkan untuk memaksimalkan pelaksanaan SPM dibutuhkan 4-6 orang kader, dan kader tersebut sebaiknya berasal dari masyarakat daerah itu sendiri.

Berdasarkan hasil penelitian yang telah dilakukan bahwa perencanaan terkait Posbindu PTM di Wilayah Kerja Puskesmas Cibungbulang dinyatakan adanya tempat pemeriksaan, meja, kursi, buku Kartu Menuju Sehat (KMS), tensimeter , alat ukur lingkar perut, alat ukur tinggi badan dan alat ukur gula darah dan kolesterol.

Menurut Kemenkes (2013), peralatan dalam pelaksanaan Posbindu PTM bernama Posbindu Kit yang terdiri dari sarana standar minimal seperti pengukur tinggi badan, timbangan berat badan, pita pengukur lingkar perut, dan tensimeter serta alat ukur analisa lemak tubuh dan media bantu edukasi dan sarana standa lengkap seperti alat ukur kadar gula darah, alat ukur kadar kolesterol total dan trigliserida, alat ukur kadar pernafasan alkohol, tes amfetamin urin kit, dan IVA kit. Untuk kegiatan deteksi dini kanker leher rahim (IVA) dibutuhkan ruangan khusus dan hanya dapat dilakukan oleh tenaga kesehatan. 
Berdasarkan hasil penelitian yang telah dilakukan bahwa dalam perencanaan posbindu PTM di Puskesmas Cibungbulang Kabupaten Bogor terdiri dari dana Bantuan Operasional Kesehatan (BOK) dan Anggaran Pendapatan dan Belanja Daerah (APBD) sedangkan untuk kader bersumber dari Anggaran Dana Desa (ADD) dan ada salah satu posbindu yang tidak memakai dana dari puskesmas dana tersebut berasal dari yayasan baitul mal (YBM) dan dana sehat dari peserta posbindu PTM sebesar 1000-5000 rupiah.

Hal ini sejalan dengan penelitian yang dilakukan oleh Nugraheni dan Hartono (2018), bahwa sumber dana posbindu berasal dari dana APBD, APBN dan BOK. Hasil penelitian Primiyani (2018), dana berasal dari pendanaan kegiatan yang bersifat preventif dan promotif yang dialokasikan untuk berbagai program pengendalian PTM termasuk Posbindu PTM baik dari pemerintah pusat maupun pemerintah daerah. Dalam anggaran biaya untuk program PTM termasuk didalamnya posbindu PTM baik yang didanai dengan APBD maupun BOK puskesmas.

Hasil penelitian dengan informan yang ditemukan informasi terkait SOP (Standar Operasional Prosedur) dan petunjuk teknis Pelaksanaan Posbindu PTM di Cibungbulang sudah ada berdasarkan SOP Dinas Kesehatan Kabupaten yang berpedoman kepada petunjuk teknis Pelaksanaan Posbindu PTM.

Berdasarkan hasil penelitian yang telah dilakukan bahwa kendala atau hambatan yang ditemukan terkait perencanaan kegiatan posbindu yaitu terkait dengan penjadwalan dan pandemi seperti sekarang ini.

Berdasarkan hasil penelitian yang telah dilakukan bahwa strategi yang dilakukan terkait dengan kendala-kendala perencanaan kegiatan posbindu tersebut yaitu dengan pengaturan jadwal kembali dan menerapkan aturan sesuai dengan SOPnya tersebut.

Hal ini sejalan dengan Juknis (2012), hari dan waktu yang dipilih sesuai dengan kesepakatan serta dapat saja disesuaikan dengan situasi dan kondisi setempat.

\section{Pengorganisasian}

Pengorganisasian yaitu sebagai cara untuk mengumpulkan orang-orang dan menempatkan mereka menurut kemampuan dan keahliannya dalam pekerjaan yang sudah direncanakan (Terry, 2019).

Berdasarkan hasil penelitian yang telah dilakukan pihak-pihak yang bekerjasama dengan puskesmas dalam pelaksanaan kegiatan Posbindu PTM di Wilayah Kerja Puskesmas Cibungbulang yaitu pihak kecamatan, pihak desa, pihak RT dan RW dan pihak kader posbindu desa tersebut. Dan bentuk kerjasama pihak kecamatan dan desa dengan puskesmas dalam pelaksanaan kegiatan Posbindu PTM yaitu dengan memberikan informasi terkait kegiatan yang akan di lakukan di dalam rapat lokakarya, mingguan, triwulan serta rapat tahunan.

Hal ini sejalan dengan Juknis (2012), camat yaitu mengkoordinasikan hasil kegiatan dan tindak lanjut Posbindu PTM di wilayah kerjanya selaku penanggung jawab wilayah kecamatan serta melakukan pembinaan dalam mendukung kelestarian kegiatan Posbindu PTM. Dan lurah/kepala desa atau sebutan lain yaitu mengkoordinasikan hasil kegiatan dan tindak lanjut Posbindu PTM di wilayah kerjanya selaku penanggung jawab wilayah desa/kelurahan serta melakukan pembinaan dalam mendukung kelestarian kegiatan Posbindu PTM. 


\section{Pelaksanaan \\ 1) Input Pelaksanaan}

Berdasarkan hasil penelitian peran SDM dalam program posbindu PTM sebelum terjadinya pandemi Covid-19 untuk kader perannya meliputi kegiatan pendaftaran, pengukuran, pelaporan dan pencatatan hasil kegiatan posbindu PTM ke puskesmas dan untuk petugas puskesmas meliputi pemeriksaan dan konseling peserta posbindu tersebut sedangkan setelah adanya pandemi Covid-19 kegiatan posbindu ditiadakan hanya melalui online saja dengan kader tetapi ada 2 posbindu yang sudah mengadakan kembali kegiatan posbindu dengan metode door to door dan metode seperti biasanya hanya saja untuk penimbangan, pengukuran dan penyuluhan saja untuk pemeriksaan oleh petugas puskesmas itu tidak ada akan tetapi itu pun sudah tidak boleh diadakan kembali bulan depannya sampai waktu yang tidak bisa ditentukan.

Hal ini sejalan dengan Juknis Kemenkes (2012), bahwa semua pegawai puskesmas wajib berpartisipasi dalam kegiatan Posbindu PTM. Penanggung jawab Posbindu PTM merupakan koordinator dalam penyelenggaraan kegiatan Posbindu PTM dan sejalan pun dengan penelitian Nugraheni dan Hartono (2018), bahwa tugas kader dalam pelaksanaan program pengendalian PTM yang dilakukan di Posbindu sudah sesuai dengan Petunjuk Teknis (Juknis) Posbindu PTM. Tugas kader yaitu mengingatkan jadwal dan mengajak masyarakat memeriksakan diri ke posbindu, menyiapkan perlengkapan posbindu termasuk form pendaftaran, peralatan dan perlengkapan pendukung seperti meja dan alat alat tulis. Bahkan kader juga menyempatkan diri untuk mengunjungi rumah masyarakat sekitar yang tidak sempat hadir datang periksa ke Posbindu PTM.

Berdasarkan hasil wawancara tentang standar kompetensi yang harus di miliki oleh pelaksana program posbindu yaitu sudah mengikuti pelatihan sedangkan untuk kader harus mengetahui tentang wawasan posbindu faktor resikonya dan setelah adanya pandemi Covid19 semua petugas pelaksana baik kader atau petugas puskesmasnya harus mengetahui tentang wawasan posbindu dan memahami protokol kesehatannya yang sudah ditentukan.

Hal ini sejalan dengan penelitian Febrianti dan Indah (2017), sebelum terjun ke lapangan para pelaksana dibekali dengan pelatihan dan bimbingan teknis. Pedoman yang digunakan dalam melaksanakan kebijakan juga konsisten. Dalam melakukan penyuluhan, materi yang diberikan di setiap pertemuan Posbindu PTM juga konsisten.

Berdasarkan hasil wawancara yang telah dilakukan bahwa tugas kader dalam pelaksanaan kegiatan posbindu PTM meliputi menginfokan terkait kegiatan, mengisi daftar hadir, mengisi buku KMS peserta, menimbang, mengukur, membagikan makanan dan mencatat laporan.

Hal ini sejalan dengan penelitian Mudatsir (2015), tugas kader dalam posbindu lansia dapat mempersiapkan sarana dan prasarana yang diperlukan pada kegiatan posbindu, memobilisasi pada hari pelayanan posbindu, melakukan pendaftaran sasaran pada posbindu lansia, melaksanakan kegiatan penimbangan berat badan, pengukuran tinggi badan lansia dan mencatatnya dalam Kartu Menuju Sehat (KMS), membantu petugas dalam pelaksanaan pemeriksaan kesehatan dan melakukan penyuluhan sesuai dengan masalah yang didapat

Berdasarkan hasil wawancara yang telah dilakukan bahwa ketersediaan sarana dan 
prasarana dalam kegiatan posbindu PTM sebelum dan sesudah terjadinya pandemi Covid-19 masih kurang lengkap.

Hal ini sejalan dengan Penelitian Annisa (2016), yang menjelaskan bahwa ketersediaan sarana dan prasarana Posbindu PTM Puskesmas Polonia belum lengkap. Sehingga pelaksanaan Posbindu PTM Puskesmas Polonia tidak dapat berjalan dengan maksimal. Tujuan program Posbindu PTM tidak akan tercapai bila tidak ada dukungan sarana dan prasarana yang memadai.

Berdasarkan hasil penelitian yang telah dilakukan bahwa dana untuk penyelenggaraan posbindu sebelum dan sesudah terjadinya pandemi Covid-19 belum sesuai standar minimal walaupun dana yang diberikan sudah ditetapkan dari BOK.

Hal ini sejalan dengan pernyataan Azwar (2010), anggaran disebut cukup apabila anggaran yang digunakan dapat mencapai sasaran sesuai perencanaan dan bermanfaat pada program tersebut.

Berdasarkan hasil penelitian yang dilakukan bahwa bentuk pelatihan yang diadakan oleh Puskesmas Cibungbulang sebelum terjadinya pandemi Covid-19 seperti pelatihan Teen Leadership Training (TLT),On The Job Training (OJT) dan workshop tentang posbindu PTM sedangkan setelah terjadinya pandemi Covid-19 hanya ada webinar untuk menambah pengetahuan.

Berdasarkan hasil penelitian yang dilakukan bahwa kader di 4 posbindu PTM di Puskesmas Cibungbulang sebelum terjadinya pandemi Covid-19 telah mendapatkan pelatihan tentang posbindu PTM walaupun tidak semua mendapatkan pelatihan. Pelatihan tersebut mengenai faktor risiko,dampak dan cara pengendalian PTM di Puskesmas Cibungbulang tetapi ada salah satu kader yang sudah mengikuti pelatihan tetapi belum diberikan pengetahuan yang cukup sedangkan setelah terjadinya pandemi Covid-19 belum ada pelatihan kembali.

Hal ini sejalan dengan hasil penelitian Pranandari, dkk (2017), pelatihan yang diterima baik dari puskesmas maupun DKK belum sepenuhnya tercakup oleh seluruh kader yang ada di desa (hanya perwakilan saja). Dengan demikian, hanya ketua kader saja yang tahu bagaimana proses pelaksanaan Posbindu PTM.

\section{2) Tahap Layanan}

Berdasarkan hasil penelitian yang telah dilakukan bahwa sistem 5 meja sebelum terjadinya pandemi Covid-19 sudah diterapkan atau dilaksanakan walaupun ada beberapa tahap yang tidak berurutan dan terkadang tahap tersebut berjalan dan tidak sedangkan setelah adanya Covid-19 posbindu yang melakukan kegiatan tersebut tidak berjalan sesuai dengan tahapannya. Hal ini sudah sesuai dengan petunjuk teknis Kemenkes 2012 pelaksanaan posbindu PTM dilaksanakan menggunakan sistem 5 meja walaupun ada beberapa tahap yang tidak berurutan dan terkadang tahap tersebut berjalan dan tidak.

Dan berdasarkan hasil penelitian yang telah dilakukan pun bahwa alur pelaksanaan yang dilakukan di posbindu PTM sebelum terjadinya Covid-19 antara lain tahap pertama peserta melakukan pendaftaran, tahap kedua wawancara, tahap ketiga penimbangan pengukuran berat badan, lingkar badan, dan tensi, tahap empat pemeriksaan kolesterol gula darah jika ada, dan tahap kelima identifikasi faktor atau konseling sedangkan setelah 
terjadinya Covid-19 tahapannya itu sama tidak ada perbedaan hanya saja mengikuti protokol kesehatannya tersebut.

\section{3) Hambatan dan Strategi Pelaksanaan}

Berdasarkan hasil wawancara yang telah dilakukan bahwa kendala atau hambatan yang ditemukan oleh kader terkait dengan pelaksanaan kegiatan posbindu yang ada di Puskesmas Cibungbulang sebelum terjadinya pandemi Covid-19 meliputi peserta yang harus dirujuk, dan partisipasi peserta tidak konsisten sedangkan kendala atau hambatan yang ditemukan oleh kader setelah adanya Covid-19 meliputi peserta yang tidak mempunyai masker, pencuci tangan dan peserta susah untuk diberitahu.

Hal ini sejalan dengan penelitian Bintang (2016), hambatan lain dalam pelaksanaan program posbindu adalah masih kurangnya kesadaran masyarakat khususnya masyarakat usia 15 tahun keatas untuk datang ke posbindu. Pengetahuan masyarakat tentang posbindu serta manfaat dan kegunaaan dari program posbindu masih sangat rendah. Agar pengetahuan masyarakat mengenai manfaat dan kegunaan posbindu baik, mereka harus mendapatkan penyuluhan khusus mengenai posbindu.

Berdasarkan hasil wawancara yang telah dilakukan bahwa terdapat kendala dan hambatan sebelum dan sesudah terjadinya pandemi Covid-19 terkait sarana dan prasarana dalam kegiatan posbindu PTM seperti ada beberapa posbindu yang tidak memiliki alat pengukuran cek kolesterol, gula darah, stik kolesterol dan gula darah, pengukuran lingkar perut, masker, pengecekan suhu dan pencuci tangan.

Berdasarkan hasil wawancara yang telah dilakukan bahwa kendala atau hambatan yang ditemukan terkait pembiayaan kegiatan posbindu sebelum terjadinya pandemi Covid-19 yaitu terkait dengan masih kurangnya biaya untuk pembelian stik dan obat sedangkan sesudah terjadinya pandemi Covid-19 lebih banyak mengeluarkan terkait masker dan pencuci tangan.

Hal ini sejalan dengan penelitian Ayu (2018), adanya keterbatasan sumber dana dapat menghambat pelaksanaan suatu program, semakin besar dana yang dikeluarkan untuk memperbaiki sebuah program maka hasilnya pun akan semakin efektif. Apabila dana yang tersedia kurang, maka program akan berjalan lambat dan tidak ada kemajuan.

\section{Pengawasan}

Pengawasan yaitu untuk mengawasi apakah gerakan dari organisasi ini sudah sesuai dengan rencana atau belum. Serta mengawasi penggunaan sumber daya dalam organisasi agar bisa terpakai secara efektif dan efisien tanpa ada yang melenceng dari rencana (Terry,2019).

Berdasarkan hasil penelitian yang telah dilakukan bahwa proses rujukan sebelum dan sesudah terjadinya pandemi Covid-19 oleh petugas puskesmas itu sama saja hanya diberikan surat rujukan kepada peserta untuk peserta datang ke puskesmas langsung.

Berdasarkan hasil penelitian yang telah dilakukan bahwa pencatatan dan pelaporan hasil kegiatan posbindu di 4 Posbindu PTM ini berbentuk buku kohort persetiap posbindu yang isinya terdiri dari nama,alamat,umur, keluhan penyakit dan data kunjung peserta.

Hal ini sejalan dengan petunjuk teknis posbindu PTM (2012), bahwa pencatatan hasil kegiatan posbindu PTM dilakukan oleh kader. Petugas puskesmas mengambil data hasil 
kegiatan posbindu PTM yang digunakan untuk pembinaan, dan melaporkan ke instansi terkait secara berjenjang. Untuk pencatatan digunakan Kartu Menuju Sehat (KMS) FR-PTM dan Buku pencatatan hasil kegiatan posbindu PTM.

Berdasarkan hasil penelitian yang telah dilakukan bahwa bentuk monitoring yang dilakukan oleh pihak puskesmas seperti dalam lokakarya mini, lokakarya bulanan dan dilihat dari hasil laporan kader setiap bulannya dan membuat laporan untuk dilaporkan ke dinas setelah itu terdapat pertemuan untuk pembahasan evaluasi laporan tersebut. Dan bahwa peran pihak puskesmas terkait pengawasan kegiatan posbindu PTM yaitu hanya dengan bentuk mereka datang memeriksa dan melihat laporan setiap bulannya.

Berdasarkan hasil penelitian yang telah dilakukan bahwa peran pihak Dinas Kesehatan terkait pengawasan kegiatan posbindu PTM yaitu hanya dengan melihat laporan setiap bulannya.

Hal ini sejalan dengan penelitian Ayu (2018), pengawasan dan evaluasi juga dilakukan oleh Dinas Kesehatan Kota Medan. Hal ini sejalan dengan ketentuan Kemenkes RI (2013), puskesmas harus melaporkan secara berkala kepada kepala dinas kabupaten/ kota dalam rangka pembinaan manajemennya sekaligus memfasilitasi untuk pembinaan teknis dari rumah sakit kabupaten, serta upaya untuk meningkatkan kerjasama dengan berbagai pihak yang terkait. Adapun pengawasan yang dilakukan oleh Dinas Kesehatan Kota Medan adalah dengan melihat laporan akhir tahun puskesmas kemudian dilakukan evaluasi program berdasarkan laporan yang diterima setiap akhir tahun sehingga akan dibahas dan ditindaklanjuti kekurangannya.

\section{KESIMPULAN}

\section{Perencanaan}

Jumlah SDM sudah mencukupi, sarana prasarana hanya terdapat tempat pemeriksaan, meja, kursi, buku KMS, tensimeter , alat ukur lingkar perut, tinggi badan dan alat ukur gula darah dan kolesterol jika yang ada, sumber pembiayaan dari dana BOK, APBD, YBM dan dana sehat dari peserta sedangkan untuk kader dari dana ADD, dan puskesmas sudah mempunyai SOP.

\section{Pengorganisasian}

Pihak-pihak yang bekerjasama yaitu pihak kecamatan, pihak desa, pihak RT dan RW dan pihak kader Posbindu desa tersebut, dan bentuk kerjasamanya yaitu dengan memberikan informasi terkait kegiatan yang akan di lakukan di dalam rapat lokakarya, mingguan, triwulan serta rapat tahunan.

\section{Pelaksanaan}

a. SDM yang bertugas pada tahapan pendaftaran, pengukuran, pelaporan dan pencatatan yaitu kader dan untuk petugas puskesmas sementara tahapan pemeriksaan dan konseling. Standar kompetensi yang harus dimiliki oleh petugas puskesmas yaitu sudah mengikuti pelatihan dan untuk kader harus mengetahui tentang wawasan posbindu faktor resikonya, sarana dan prasarana masih kurang lengkap, pembiayaan untuk penyelenggaraan posbindu sebelum dan sesudah terjadinya pandemi Covid-19 belum sesuai standar minimal, Yang mendapat pelatihan yaitu penanggung jawab, pelaksana dan kader program posbindu PTM. Kader di 4 posbindu PTM telah mendapatkan pelatihan walaupun tidak semua mendapatkan pelatihan. 
b. Sistem 5 meja sebelum terjadinya pandemi Covid-19 sudah diterapkan di setiap posbindu PTM walaupun ada beberapa tahap yang tidak berurutan dan terkadang tahap tersebut berjalan dan tidak sedangkan setelah adanya Covid-19 posbindu yang melakukan kegiatan tersebut tidak berjalan sesuai dengan tahapannya. Alur pelaksanaan kegiatan posbindu PTM yaitu tahap pertama pendaftaran, tahap kedua wawancara, tahap ketiga pengukuran, tahap empat pemeriksaan, dan tahap kelima identifikasi faktor atau konseling.

\section{Pengawasan}

Proses rujukan hanya diberikan surat rujukan untuk peserta datang ke puskesmas langsung. Pencatatan dan pelaporan hasil kegiatan berbentuk buku kohort persetiap posbindu. Bentuk monitoring pihak puskesmas seperti dalam lokakarya mini, lokakarya bulanan dan hasil laporan kader setiap bulannya, pengawasan dinas kesehatan yaitu hanya dengan melihat laporan setiap bulannya

\section{DAFTAR PUSTAKA}

Annisa, Nina. 2016. Analisis Pelaksanaan Program Pos Pembinaan Terpadu Penyakit Tidak Menular Di Wilayah Kerja Puskesmas Polonia Kecamatan Medan Polonia Tahun 2016. Universitas Sumatera Utara. Dikutip pada tanggal 8 Februari 2020

Arikunto, 2013. Prosedur Penelitian: Suatu Pendekatan Praktik. Jakarta: Rineka Cipta.

Arikunto, 2010. Dasar-Dasar Evaluasi Pendidikan. Jakarta: Bumi Aksara.

Association, American Heart. 2015. Coronary artery diseases.

Astuti ED, dkk 2016. Gambaran Proses Kegiatan Pos Pembinaan Terpadu Penyakit Tidak Menular Di Puskesmas Sempu Kabupaten Banyuwangi. Universitas Jember. Jawa Timur. E- Jurnal Pustaka Kesehatan 4 (1): 160- 167. Dikutip pada tanggal 10 Februari 2020.

Ayu, Yovi 2018. Pelaksanaan Program Pos Pembinaan Terpadu Penyakit Tidak Menular Di Wilayah Kerja Puskesmas Kota Matsum Tahun 2018. Universitas Sumatera Utara.

Ayuningtyas, Dumilah, Misnaniarti Misnaniarti, Siti Khodijah Parinduri, Fitria Aryani Susanti,

Ni Nyoman Dwi Sutrisnawati, and Sayyidatul Munawaroh. "Local Initiatives In Preventing Coronavirus Based On Health Policy Perceptive." Journal of Indonesian Health Policy and Administration 5, no. 2 (2020).

Ayuningtyas,D., Parinduri,S. K.dan Susanti, F. A. 2018. Integritas Kepemimpinan Antikorupsi di Sektor Kesehatan.Jurnal Integritas 4(1): 5.

Asnifatima A, Parinduri SK, Aligori A. (2020). Risiko dan Karakteristik Penderita Toksoplasmosis berdasarkan Demografi, Keberadaan Hewan Peliharaan, Hygiene dan Sanitasi. Heart, Jurnal Kesehatan Masyarakat,8(X), 41-49.

A Nasution, A Maulana, D Kurniawan. (2019). BERSAMA MEMAJUKAN DESA. Abdi Dosen: Jurnal Pengabdian Pada Masyarakat 3 (2), 99-104

B. Rizki, D. Fitriana, R. Hidana, S.K. Parinduri, Analisis Penerapan Sistem Informasi Manajemen Puskesmas (Simpus) dengan Model Human Organization Technology (HOT)-Fit di Puskesmas Tanah Sareal Kota Bogor Tahun 2019 Pendahuluan Metode, PROMOTOR: Jurnal Mahasiswa Kesehatan Masyarakat 3(1) (2020) 18-27.

Bintang,Sri. 2016. Pelaksanaan program pos pembinaan terpadu penyakit tidak menular (posbindu ptm) pada penderita hipertensi di puskesmas padang bulan tahun 2016. Universitas Sumatera Utara. Medan. 
Bustan, M.N. 2015. Epidemiologi Penyakit Tidak Menular Edisi Revisi. Jakarta: Rineka Cipta. Bustan. 2007. Epidemiologi Penyakit Tidak Menular. Jakarta: Rineka Cipta.

Dwimawati, E., Yanuaringsih, G.P., Pangaribuan, R., ...Gurning, F.P., Pratama, M.Y. (2021). Smoke exposure at home to the incidence of pneumonia in children under 5 years old. Indian Journal of Forensic Medicine and Toxicologythis link is disabled, 2021, 15(1), pp. 1872-1878

Dwimawati, E., \& Anisa, N. (2018). Faktor-faktor yang berhubungan dengan pengetahuan kesehatan reproduksi remaja di SMK YAK 1 bogor kecamatan tanah sareal kota Bogor provinsi Jawa Barat tahun 2018. PROMOTOR, 1(2), 80-86.

D.N. Afiyani, E. Dwimawati, S. Pujiati. (2020). Gambaran Status Gizi Berdasarkan Antropometri Pada Mahasiswa Fakultas Ilmu Kesehatan Masyarakat Universitas Ibn Khaldun Bogor. PROMOTOR 3 (1), 50-55.

Damayanti, Fanny Azryna. 2018. Analisis Pelaksanaan Program Pos Pembinaan Terpadu Penyakit Tidak Menular (POSBINDU PTM) di Puskesmas Glugur Darat Tahun 2018. Universitas Sumatera Utara.

Departemen Kesehatan RI. 2009. Undang-Undang Republik Indonesia Nomor 36 Tahun 2009 Tentang Kesehatan. Jakarta : Kementerian Kesehatan RI : 2009.

Departemen Kesehatan RI. 2014. Peraturan Menteri Kesehatan Nomor 75 Tahun 2014 Tentang Pusat Kesehatan Masyarakat (Puskesmas). Jakarta.

Departemen Kesehatan RI. 2016. Peraturan Menteri Kesehatan Nomor 43 Tahun 2016 Tentang Standar Pelayanan Minimal (Spm) Bidang Kesehatan. Jakarta.

Dinas Kesehatan Kabupaten Bogor. 2018. Profil Kesehatan Kabupaten Bogor Tahun 2018.

Direktorat Jendral Pencegahan dan Pengendalian Penyakit. 2019. Buku Pedoman Manajemen Penyakit Tidak Menular.

E. Dwimawati, F. Beliansyah, S.A. Zulfa. (2019). Pemberdayaan Masyarakat Melalui Pemanfaatan Teknologi Dalam Rangka Meningkatkan Kualitas Sumber Daya Manusia Di Desa Gunung Menyan. Abdi Dosen: Jurnal Pengabdian Pada Masyarakat 3 (1). Keputusan Menteri Kesehatan Republik Indonesia. (2007). 377/Menkes/SK/III/2007 Tentang Standar Profesi Perekam Medis dan Informasi Kesehatan. Jakarta

Effendi. 2009. Manajemen Pusat Kesehatan Masyarakat. Jakarta: Salemba Medika.

Fatmah, 2013, Pengaruh Pelatihan pada Peningkatan Pengetahuan dan Keterampilan Teknis Penyuluhan Obesitas dan Hipertensi Kader Posbindu Kota Depok. Universitas Indonesia. Dikutip pada tanggal 26 Agustus 2020.

Febrianti R, Indah P. 2017. Implementasi Pelaksanaan Pos Pembinaan Terpadu Penyakit Tidak Menular (Posbindu Ptm) Di Puskesmas Pucang Sewu Kota Surabaya. Universitas Negeri Surabaya. Dikutip pada tanggal 10 Februari 2020.

Fitrianingtyas, Pertiwi, dan Rachmania, W. Faktor-Faktor yang Berhubungan dengan Kejadian Kurang Energi Kronis (KEK) pada Ibu Hamil di Puskesmas Warung Jambu Kota Bogor. HEARTY Jurnal Kesehatan Masyarakat. 2018;6(2):1-8.

Hariwijaya. 2017. Pengertian Wawancara Mendalam Eprints.Umm.Ac.Id Irwan. 2016. Epidemilogi Penyakit Tidak Menular. Yogyakarta: Deepublish. Jansje H, V. Ticoalu \& Yoseph L

Samodra. 2014. Prevalensi Penyakit Tidak Menular Pada Tahun 2012-2013 Di Kecamatan 
Airmadidi Kabupaten Minahasa Utara Sulawesi Utara

Kementerian Kesehatan RI. 2012. Petunjuk Teknis Pos Pembinaan Terpadu Penyakit Tidak Menular. Direktorat Jenderal Pengendalian Penyakit dan Penyehatan Lingkungan Direktorat Pengendalian Penyakit Tidak Menular. Jakarta.

Kementerian Kesehatan RI. 2013. Pedoman Teknis Penyelenggaraan Pengendalian Penyakit Tidak Menular di Puskesmas. Jakarta.

Kementerian Kesehatan RI. 2013. Riset Kesehatan Dasar; RISKESDAS. Jakarta: Badan Penelitian Dan Pengembangan Kesehatan Kementerian Kesehatan RI.

Kementerian Kesehatan RI. 2014. Pedoman Umum Pos Pembinaan Terpadu Penyakit Tidak Menular Direktorat Jenderal Pengendalian Penyakit dan Penyehatan Lingkungan Direktorat Pengendalian Penyakit Tidak Menular. Jakarta.

Kementerian Kesehatan RI. 2016. Profil Penyakit Tidak Menular 2016. Jakarta.

Kementerian Kesehatan RI. 2017. Profil Kesehatan Indonesia Tahun 2017. Jakarta.

Kementerian Kesehatan RI. 2019. Riset Kesehatan Dasar; RISKESDAS. Jakarta: Badan Penelitian Dan Pengembangan Kesehatan Kementerian Kesehatan RI.

Kementerian Kesehatan RI. 2020. Pedoman pencegahan dan pengendalian coronavirus disease (Covid- 19). Jakarta.

Maryam, siti. 2010. Buku Panduan Bagi Kader Posbindu Lansia. Jakarta: Trans Info Media.

Mudatsir, Maulida Hermansyah. 2015. Komunikasi Dan Koordinasi Kader Dengan

Pelaksanaan Posbindu Lansia. Universitas Syiah Kuala, Banda Aceh. Jurnal Ilmu

Keperawatan ISSN: 2335- 6371. Dikutip 25 Agustus 2020.

Nasruddin, Nurizka Rayhana. 2017. Faktor-Faktor Yang Mempengaruhi Pemanfaatan Pos Pembinaan Terpadu Penyakit Tidak Menular (Posbindu Ptm) Di Wilayah Kerja Puskesmas Ballaparang Kota Makassar Tahun 2017. Uin Alauddin Makassar.

Notoatmodjo. 2010. Promosi Kesehatan Dan Perilaku Kesehatan. Jakarta: Rineka Cipta.

Nugraheni WP, Hartono RK. 2018. Strategi penguatan program posbindu penyakit tidak menular di kota Bogor. Jurnal Ilmu Kesehatan Masyarakat 9(3): 198-206. Dikutip pada tanggal 19 agustus 2020

N. Oktaviani, I. Avianty, and E. D. Mawati, "Faktor-Faktor Yang Berhubungan Dengan Perilaku Merokok Pada Mahasiswa Pria Di Universitas Pakuan Bogor Provinsi Jawa Barat Tahun 2018," Promotor, vol. 2, no. 1, p. 44, 2019, doi: 10.32832/pro.v2i1.1788.

Novitasari, Y., Mawati, E. D., \& Rachmania, W. (2019). Faktor-Faktor Yang Berhubungan Dengan Perilaku Pemberian Asi Ekslusif Di Puskesmas Tegal Gundil Kota Bogor Jawa Barat Tahun 2018. PROMOTOR Jurnal Mahasiswa Kesehatan Masyarakat, 2(4), 324-333. https://doi.org/http://dx.doi.org/10.32832/pro.v2i4.2246.

Pertiwi, F. D., Hariansyah, M., \& Prasetya, E. P. (2019). FAKTOR RISIKO STUNTING PADA BALITA DIKELURAHAN MULYAHARJA TAHUN 2019. PROMOTOR, 2(5). https://doi.org/10.32832/pro.v2i5.2531

Pertiwi, F. D., Rahman, R. M., \& Lestari, D. W. (2018). Pemberdayaan masyarakat melalui bidang literasi di Desawaru Jaya. Jurnal ABDI DOSEN: Jurnal Pengabdian Pada Masyarakat, 2(2), 129-137. https://doi.org/10.32832/abdidos.v2i2.170

P. S. Akbar, S. K. Parinduri, and R. Hidana, "Gambaran Pelaksanaan Surveilans Epidemiologi Di Rumah Sakit Umum Daerah Leuwiliang Kabupaten Bogor Tahun 2018,” PROMOTOR, vol. 
2, no. 5, pp. 410-421, 2019.

Parinduri, Siti Khodijah dan Pujiyanto. 2018. The Factors of Management, Communication, Partnership, and Innovation in the Implementation of Posbindu (Integrated Health Post) NCD: A Study in Kelurahan Gunung Batu Bogor City. University of Ibn Khaldun Bogor. Dikutip pada tanggal 3 September 2020

Parinduri, Siti Khodijah. 2015. Analisis Pelaksanaan Program Pos Pembinaan Terpadu Penyakit Tidak Menular (Posbindu Ptm) Dalam Deteksi Dini Dan Pencegahan Komplikasi Diabetes Melitus Di Puskesmas Glugur Darat Tahun 2014. Universitas Sumatera Utara. Dikutip pada tanggal 4 Februari 2020

Pranandari LL, dkk. 2017. Analisis Implementasi Program Pos Pembinaan Terpadu Penyakit Tidak Menular (Posbindu PTM) Di Kecamatan Banguntapan Kabupaten Bantul. Jurnal kesehatan Masyarakat (e-journal) 5 (4):76-85. Dikutip pada tanggal 27 Agustus 2020.

Primiyani,Yulia. 2019. Analisis Pelaksanaan Program Pos Pembinaan Terpadu Penyakit Tidak Menular Di Kota Solok. Universitas Andalas. Jurnal Kesehatan Andalas 8(2): 399-406. Dikutip pada tanggal 20 Agustus 2020.

Pudiastuti, Dewi. 2011. Penyakit Pemicu stroke (Dilengkapi Posyandu Lansia dan Posbindu PTM). Jawa Tengah: Nuha Medika.

Puskesmas Cibungbulang. 2018. Profil Puskesmas Cibungbulang Tahun 2018. Bogor

Putri Ramadhani Eka, dkk. 2017. Evaluasi Proses Implementasi Posbindu Ptm Di Wilayah

Kerja Puskesmas Simpang Sungai Duren Kecamatan Jambi Luar Kota Kabupaten Muaro Jambi Tahun 2017. Universitas Jambi. Jurnal Kesehatan masyarakat Jambi 2(1): 12-27. Dikutip pada tanggal 19 Agustus 2020

Rahmayanti, Elyda dan Arief Hargono. 2017. Implementasi Surveilans Faktor Risiko Penyakit Tidak Menular Berbasis Posbindu Berdasarkan Atribut Surveilans (Studi di Kota Surabaya). Universitas Airlangga Surabaya. Dikutip pada tanggal 19 agustus 2020

Restuastuti Tuti, Ridha Restila. 2018. Analisis Pemberdayaan Masyarakat Sebagai Upaya Pencegahan Penyakit Tidak Menular Melalui Posbindu Ptm Di Kecamatan Xiii Koto Kampar Kabupaten Kampar Riau. Asian Journal of Environment, History and Heritage 2(1). Dikutip pada tanggal 2 Maret 2020

Sari MM, Nurkamila N, Mawati ED. Faktor-Faktor yang Mempengaruhi Kepatuhan Ibu Hamil dalam Melakukan Pemeriksaan Kehamilan di Puskesmas Cibungbulang Kabupaten Bogor Provinsi Jawa Barat Tahun 2018. Jurnal Mahasiswa Kesehatan Masyarakat [Internet]. 2018;1(2):96-103. Available from: http://ejournal.uikabogor.ac.id/index.php/PROMOTOR/article/view/1595

Saputra MH, dkk. 2017. Analisis sistem informasi faktor resiko hipertensi berbasis posbindu di dinas kesehatan Kabupaten Sidoarjo. Prosiding Seminar Nasional. Seri Ke-1 Tahun 2017.

Sicilia G, dkk. 2018. Evaluasi Kualitatif Program Pengendalian Penyakit Tidak Menular Berbasis Posbindu Di Wilayah Kerja Puskesmas Muara Bungo I. Universitas Gadjah Mada. Jurnal Kebijakan Kesehatan Indonesia: JKKI 7 (2): 88- 92. Dikutip pada tanggal 3 Maret 2020.

Soendari. 2015. Pengujian Keabsahan Data Penelitian Kualitatif Repository.Upi.Edu Sugiyono. 2015. Metode Penelitian Kombinasi. Bandung: Alfabet 
Sugiyono. 2016. Metodologi Penelitian Kualitatif Dan R \& D. Bandung: Alfabeta

Sutrisno, Edy. 2011. Manajemen Sumber Daya Manusia. Jakarta: Kencana

Tambunan, Rudi, M. 2013. Pedoman Penyusunan Standar Operating Prosedures (SOP). Edisi Kedua, Jakarta: Maiestas Publishing

Terry, George R. 2014. Prinsip-Prinsip Manajemen. Bumi Aksara.

Terry, George R. 2019. Principles Of Management.

World Health Organization. 2011. Global Status Report On Noncommunicable Diseases 2010.

World Health Organization. 2014. Global Status Report On Noncommunicable Diseases 2014. 